\title{
Kan Steinerskolens historie inspirere vår tids skoledebatt?
}

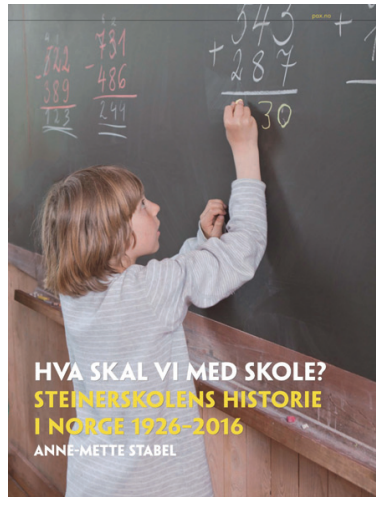

Anne-Mette Stabel: Hva skal vi med skole?

Steinerskolens historie $i$ Norge 1926-2016, PAX-forlag, 2016, 334 sider

\section{Innledning}

Anne-Mette Stabels bok Hva skal vi med skole? er en bearbeiding av hennes doktorgradsavhandling fra 2014, Visjoner og vilkår. Om Steinerskolens utvikling $i$ Norge fra 1926-2004. Boka kan med første øyekast fremstå som en leksikalsk utskrivning av Steinerskolens historie i Norge gjennom de siste 90 årene. Den kan derfor bli ansett som lite relevant utenfor steinerpedagogiske kretser, selv om Steinerskolens historie åpenbart er en hvit flekk på kartet over norsk skolehistorie som Stabel fyller på en flott måte. Det er derimot ikke vanskelig å se at den har en intensjon om å kunne bidra inn i en bredere skoledebatt enn som så.

Tittelen gir indikasjoner om dette. Den reiser et grunnleggende spørsmål om skolens samfunnsmandat som enhver diskusjon om danning vs. kompetanse eller input vs. output i bunn og grunn dreier seg om. Gjennom å analysere Steinerskolenes måte å forstå og presentere seg selv og sitt mandat gjennom disse 90 årene, forsøker Stabel å vise hvordan Steinerskolen har plassert seg i dette landskapet. Datamaterialet Stabel har brukt for å gjøre disse analysene er skrevne tekster i form av læreplaner, artikler i interne steinerpedagogiske tidsskrift og debattinnlegg i offentlige media. Dette er med andre ord ikke en beskrivelse av steinerpedagogisk praksis, men en analyse av hvordan disse skolene har formulert intensjonene med sitt arbeid skriftlig gjennom 90 år. Og kildetilfanget synes å være omfattende og mangfoldig.

Stabel tar oss med fra Arbeiderpartiets idé om en to sosialt utjevnende enhetsskole i førkrigsårene, via 50- og 60-tallets instrumentelle positivismepregede skole 
og 70-tallets dialogpedagogiske eksperiment fram til PISA-sjokk, målstyring og New Public Management. Hun viser hvordan skiftende skolepolitiske trender gjennom tidene har forholdt seg til privat skoledrift generelt og til Steinerskolen som et pedagogisk alternativ spesielt. Stabel avslutter boka med følgende utsagn: « ... fortellingen om Steinerskolen viser [.. .] at det er mulig å tenke annerledes om både barn og skole og utdanning enn det som gjøres innenfor dagens utdanningsdebatt» (2016, s. 273). Hvor tydelig er denne alternative tenkningen presentert, og i hvilken grad kan den spille en rolle i dagens skoledebatt?

\section{Hva skal vi med skole ifølge Steinerskolen?}

Stabel innleder boken sin med en presentasjon av Rudolf Steiners idéverden, antroposofi, som en bakgrunn for å forstå hva som er grunnlaget for Steinerskolens mandatforståelse. Hun beskriver dette uten særlig grad av kritisk refleksjon, men det gir allikevel en god grunnforståelse for hvilke premisser Steinerskolen legger til grunn for sin virksomhet. Jeg vil trekke frem to moment.

Steiners idé om barns langsomme utvikling medførte at Steinerskolene var forut for sin tid med hensyn til å etablere et 12-årig allmenndannende skoleløp uten sortering. Skolen skulle være et sted for å støtte opp om den langsomme modningen av barnet uten at det skulle skjeles til samfunnets behov for spesialisering. Et eksempel på en slik utviklingsdidaktisk tenkning er ideen om at skolen først lar elevene oppleve et undervisningsinnhold på et sansemessig og emosjonelt plan, for så å vende tilbake til det samme innholdet flere år senere, for da å vekke elevenes refleksjon og kritisk dømmekraft omkring det.

Kanskje enda viktigere enn dette var den omfattende sosiale visjonen for kulturens og menneskets fremtid som lå til grunn for etableringen av den første Waldorfskolen. Steiner sto for en, riktignok spirituelt inspirert, kosmopolitisk tenkning, som innebar at mennesker på tvers av rase, kjønn, etnisitet og religion kunne gjenerobre et felles moralsk-etisk grunnlag for sameksistens gjennom utvikling av hvert enkelt individs potensial. Skolen skulle være et sted hvor dette kunne vekkes. Tekstene Stabel har lest har en tendens til å omtale dette som å vekke sovende åndelige krefter i barna gjennom en bestemt måte å arbeide med et bestemt undervisningsinnhold.

Stabel viser hvordan en slik danningsidé kom til uttrykk i skoledebatten på 50- og 60-tallet, ikke minst gjennom tekstene til kritiske samfunnsdebattanter med en fot i steinerskolemiljøene som Jens Bjørneboe, Karl Brodersen, Ernst Sørensen med flere. Stabel henviser til Bjørneboes artikkel Skal vi sette våre barn på Steinerskolen? for å få frem skolens danningsideal. Her spissformulerer han skolens intensjon slik: «Det finnes bare ett riktig spørsmål å stille om skole eller en oppdragelsesform. [...] Blir man mer menneske av den?» (Bjørneboe, 1976, s. 18). A bli menneske ble satt ord på i læreplanen som en tredelt prosess hvor skolens mål var å bidra til «fordomsfritt tenkende, varmt følende og moralsk handlende mennesker» (Stabel, 2016, s. 102). En annen steinerpedagogisk skribent Stabel trekker frem, Dan Lindholm, sa det slik: «Sett fra et virkelig kultursynspunkt, fra et menneskeoppdragende synspunkt, blir hvad og hvor meget der læres av forsvinnende betydning sammenlignet med hvordan 


\section{Dag Oystein Nome}

tingene læres, hvordan den pedagogiske praksis øves» (2016, s. 71). Steinerskolen anser på denne måten læring mer som et middel enn som et mål i skolen, og refleksjoner rundt valg av innhold og arbeidsmåter får derfor en sentral plass. Stabel viser hvordan dette medførte at steinerpedagoger som Bjørneboe og Brodersen kastet seg inn i den skolepolitiske debatten med et brennende engasjement, og håpet var å endre en skolepolitisk tenkning preget av instrumentalisme og en teknisk rasjonell vitenskapliggjøring av undervisning, ikke ulikt dagens utdanningspolitiske debatt.

Steinerskolens intensjon, slik Stabel fremstiller den, fremstår med en annen forståelse av skolens samfunnsmandat enn den rådende skolepolitiske trenden, enten det dreier seg om 50- og 60-tallets instrumentelle pragmatisme eller dagens PISA-orienterte målstyringsregime. Skole er ifølge en slik tenkning en langsom, uforutsigbar og ikke målbar eller standardisert prosess for å vekke moralske krefter i barna på tvers av nasjonale, kulturelle og etniske skillelinjer. Da er innhold og arbeidsmåter viktigere enn resultatet og testregimer, slutteksamen, nyttetenkning og bruk av karakterer. Men hvordan forholder dette seg til annen danningsteoretisk tenkning?

\section{Steinerskolen i et danningsteoretisk landskap}

Steinerskolens svar på spørsmålet Hva skal vi med skole? samsvarer slik jeg ser det med en rekke klassiske danningsteoretiske idéer. Den tyske filosofen og universitetsstifteren Wilhelm von Humboldt (1767-1835) beskrev for eksempel danning som en prosess hvor individet gjorde seg til representant for det genuint menneskelige samtidig som det virkeliggjorde sine unike personlige kvaliteter (Humboldt, 2000). I følge Humboldt er det genuint menneskelige noe som overskrider både det individuelle så vel som det kulturelle. Det er med andre ord mer enn det vi vanligvis forstår som sosialisering til en bestemt kultur. Humboldt målbar ideen om verdensborgeren som ideal. Hans bror, den filantropiske geografen Alexander von Humboldt, uttrykte denne ideen som: «... å behandle hele menneskeheten uten hensyn til religion, nasjonalitet eller farve, som en stor forbrødret stamme» (Humboldt, 1997, s. 385). Det samme danningsidealet ble uttrykt av Schiller (1991), forøvrig en filosof Steiner uttrykte stor begeistring for, ifølge Stabel.

Skolen har dessuten gjennom alle tider vært gitt en betydning utover den umiddelbare tilegnelsen av kunnskaper og ferdigheter. John Lock uttrykte det allerede i 1693 slik: «Boklig lærdom må deres sønn ha, men i annen rekke, bare som middel og medvirkning til egenskaper av større betydning» (Locke, 2006, s. 87). Tilegnelse av et undervisningsinnhold blir dermed ansett som et middel og ikke som et mål i seg selv, slik Stabel også presenterer steinerpedagogikken.

En slik idé går som en understrøm gjennom skoles idéhistorie fra Lock, via den tyske åndsvitenskapen som kulminerte med Wolfgang Klafki (2001), til dagens kritiske skoletenkere som Stefan Hopmann (2013) og Giert Biesta (2014). Hopmann har poengtert betydningen av innholdsdimensjonen i skolen, og han problematiserer et for sterkt output-fokus, fordi det nedvurderer betydningen av den enkelte elevs 
personlige opplevelse av mening i møte med et undervisningsinnhold (Hopmann, 2010). Biesta på sin side er kritisk til læringsfokuset i skolen og løfter frem undervisningsdimensjonen, altså det didaktiske møtet mellom elev, lærer og et innhold, som viktigere for skolens selvforståelse enn leringsdimensjonen (Biesta, 2006). Han gir også skolen oppgaven med å vekke elevenes mot til å påta seg et moralsk ansvar for verden. Et slikt danningsideal kan sammenfattes i Hannah Arendts formulering om at: «Dannelse er det punkt hvor vi avgjør om vi elsker verden høyt nok til å påta oss ansvaret for den» (Arendt, 2006, s. 369). Og dette vil Steinerskolen lett slutte seg til, slik Stabel beskriver dens selvforståelse.

\section{Hva kan Steinerskolen bidra med i dagens skoledebatt?}

Ved å gi boken tittelen Hva skal vi med skole? indikerer Stabel at Steinerskolen har et svar å gi som er av betydning for dagens skolepolitiske ordskifte. Det er åpenbart at Steinerskolens selvforståelse er i tråd med flere sentrale danningsteoretiske ideer, og den bør kunne ha et bidrag å komme med i kritikken mot dagens målstyringspregede output-skole. Derfor burde denne boka kunne være et forfriskende innspill i den pågående utdanningsdebatten.

Stabel har riktignok en tilleggsagenda. Hun avslutter boka med en diskusjon om Steinerskolens fremtid og spesielt hvordan den bør forholde seg til antroposofi som idégrunnlag. Stabel er selv Steinerpedagog og arbeider til daglig som førsteamanuensis ved Rudolf Steinerhøyskolen, og det gjør det naturlig for henne å gi boken denne innretningen. Men det medfører at boka, på to måter, vil ha problemer med å bli den kritiske stemmen den kunne ha blitt i debatten.

For det første fordi Stabel ikke besvarer spørsmålet sitt i boka godt nok, siden avslutningskapitlet er så sterkt preget av en intern agenda om å posisjonere Steinerskolene for fremtiden. For det andre fordi Stabel i avslutningskapitlet viser at forholdet til antroposofi fortsatt synes uavklart i Steinerskolene. Det er åpenbart problematiske sider ved dette idégrunnlaget som står $\mathrm{i}$ veien for å inkludere Steinerskolen i en allmenn skoledebatt. At interessen for å forske på Steinerskolens praksis har vært laber, er ifølge Stabel selv, noe som skyldes antroposofiens status. Stabel viser hvordan opprinnelsen til skolen hadde et sterkt åndelig preg over seg, og det vises også ved at skolens danningsoppdrag ofte beskrives som å vekke sovende åndelige krefter i barnas natur. Det er dessuten bibelske dimensjoner over Steinerskolenes opprinnelse. Stabel beskriver hvordan Steiner kalte til seg 12 utvalgte lerere, underviste dem og ga dem, det han selv kalte, «en hellig religiøs forpliktelse» for å arbeide som lærere (2016, s. 32). Insisteringen på at Steinerskolen allikevel ikke er en livssynsskole står lagelig til for hugg.

Stabel innrømmer at dette er problematisk og forsøker å ta tak i denne krevende materien ved å inspirere det steinerpedagogiske miljøet til å bearbeide, forske på og fornye sitt idégrunnlag for derigjennom å gjøre seg bedre rustet til å delta $\mathrm{i}$ en allmenn skoledebatt. Det er sikkert gode grunner for å skynde seg langsomt, med tanke på å ha hele steinerskolemiljøet med på en modernisering av skolens idégrunnlag, og det er bare å ønske lykke til med det arbeidet. Vi trenger flere 
stemmer til forsvar for skolens innholdsside og, som Stabel sier, «... at det er mulig å tenke annerledes om både barn og skole og utdanning enn det som gjøres innenfor dagens utdanningsdebatt» (2016, s. 273).

Dag Oystein Nome

University of Agder, Norway

\section{Referanser}

Arendt, H. (2006). Utdanningskrisen. I T. Kroksmark (Red.), Den tidløse pedagogikken (s. 355-370). Bergen: Fagbokforlaget.

Biesta, G. J. J. (2006). Beyond learning: democratic education for a human future. Boulder, Colo: Paradigm Publ. Biesta, G. J. J. (2014). The beautiful risk of education. Boulder, Colo: Paradigm Publ.

Bjørneboe, J. (1976). Under en mykere himmel: Brev og bud fra en Steinerskole. Oslo: Gyldendal.

Hopmann, S. (2010). Undervisningens avgrensning: Didaktikkens kjerne. I J.H. Midtsundstad \& I. Willberg (Red.), Didaktikk - Nye teoretiske perspektiver på undervisningen (s. 19-43). Oslo: Cappelen Akademiske forlag.

Hopmann, S. (2013). The end of schooling as we know it? fournal of Curriculum Studies, 45(1), 1-3. doi: $10.1080 / 00220272.2013 .767570$

Humboldt, A. v. (1997). Cosmos: a sketch of a physical description of the universe. Baltimore: Johns Hopkins University Press.

Humboldt, W. v. (2000). Theory of bildung. I S. Hopmann, I. Westbury \& K. Riquarts (Red.), Teaching as a reflective practice: The German didaktik tradition (s. 57-62). New York: Routledge.

Klafki, W. (2001). Dannelsesteori og didaktikk - Nye studier. Århus: Forlaget Klim.

Locke, J. (2006). Noen tanker om utdannelse. I T. Kroksmark (Red.), Den tidløse pedagogikken (s. 87-95). Bergen: Fagbokforlaget.

Schiller, F. (1991). Om menneskets estetiske oppdragelse $i$ en rekke brev. Oslo: Solum Forlag.

Stabel, A.-M. (2016). Hva skal vi med skole? Steinerskolens historie i Norge 1926-2016. Oslo: Pax forlag. 